\title{
Pembuatan Virgin Coconut Oil (VCO) Menggunakan Enzim Bromelin di Kampung Kekupu, Depok
}

\author{
Elfia Siska Yasa Putri ${ }^{1 *}$, Wijiastuti ${ }^{2}$, Herlina Boedhi Setijanti ${ }^{3}$ \\ ${ }^{1,3}$ Program Studi Farmasi, ${ }^{2}$ Program Studi D4 Analis Kesehatan \\ ${ }^{1,2,3}$ Fakultas Farmasi dan Sains, Universitas Muhammadiyah Prof Dr Hamka- Islamic Center \\ Jalan Delima Raya II/IV Perumnas Klender, Jakarta Timur \\ "e-mail corresponding author : elfia.siska@uhamka.ac.id. No. HP 085280746660
}

\begin{abstract}
ABSTRAK
Kampung Kekupu Depok tergolong ekonomi kebawah dimana pekerjaan kepala keluarganya tidak mencukupi kebutuhan hidup. Ibu-ibu yang ada di daerah ini hampir sebagian besar berprofesi sebagai ART (Asisten Rumah Tangga). Di daerah ini banyak ditumbuhi buah nenas yang hanya dimanfaatkan sebagai olahan makanan atau minuman seperti selai, es buah, Disamping itu salah satu kandungan buah nanas adalah bromelin yaitu suatu enzim yang dapat digunakan sebagai pengendap dalam pembuatan VCO dari santan kelapa. VCO adalah minyak kelapa yang dibuat dari bahan baku kelapa segar, yang diproses salah satunya dengan cara enzimatis menggunakan enzim tertentu. Kegiatan ini bertujuan untuk (1) meningkatkan pengetahuan mitra tentang VCO (2) mengajarkan cara pembuatan dan pengemasan $V C O$ sehingga mitra bisa secara mandiri untuk memproduksi $V C O$. Pada kegiatan pengabdian ini dilakukan pemberian informasi cara pembuatan $V C O$ melalui cara enzimatis dengan memanfaatkan tumbuhan buah nanas (Ananas comosus) yang ditanam di Kampung Kekupu, Depok.. Dengan demikian, mitra dapat membantu penghasilan keluarga. Pada tahap pembuatan $V C O$ ini, enzim bromelin dari buah nanas yang dicampur dengan krim kelapa. Setelah itu $V C O$ yang terbentuk diambil menggunakan sendok sayur dan dikemas dalam wadah yang aman. Untuk menunjang kegiatan ini maka mitra diberikan buku saku panduan pembuatan VCO menggunakan enzim bromelin. Penyuluhan tentang zat-zat kimia yang terkandung dalam buah kelapa, buah nenas, dan $V C O$ serta manfaat dan keunggulan $V C O$ diberikan oleh narasumber. Pada akhir kegiatan terlihat antusias nya para peserta untuk membuat VCO secara mandiri
\end{abstract}

Kata kunci : enzim bromelin; virgin coconut oil

\section{ABSTRACT}

The population in Depok's Kekupu village is classified as a low-class economy because the income of the head of the family is not enough to fulfill the needs of daily living.Furthermore, their wives are mostly household assistant.There are many pineapples are planted in this village that are utilised as diets, for instance jam and fruit ice and beverages. One of the contents of the pineapple is a bromelin enzyme that can be used as a precursor in the manufacture of VCO from coconut milk. VCO (virgin Coconut Oil) is coconut oil made from fresh coconut raw materials, one of processing by specific enzyme. Team of dedication trained about production of VCO that used

Cara Mengutip : Putri, E.S., Wijiastuti, W., Setijanti, H. B. (2020). Pembuatan Virgin Coconut Oil (VCO)

Menggunakan Enzim Bromelin di Kampung Kekupu, Depok. JAST : Jurnal Aplikasi Sains dan Teknologi, 4 (1), 38-43. doi:http://dx.doi.org/10.33366/jast.v4i1.1557 
enzymatic method. Furthermore, this method utilized pineapples (Ananas comosus) that be planted in Kampung Kekupu, Depok. The dedication have many intentions for the partner (1) to increase knowledge about VCO (2) to teach about the ways of making and packaging VCO so that the partner can produe VCO independently. Perhaps the population of Kampung kekupu add family income. Thera were many steps to obtain VCO. First, the bromelin enzyme from the pineapple is mixed with the coconut cream. After that, VCO was taken by the ladle. This VCO was packed in a safe container. The handbook of procedure VCO was given to the partner to support this activity. The team delivered about chemical content of coconut, pineapple, and VCO. In addition, th partner gained information about benefits of VCO. At the end of the activity the participants were enthusiastic to create a VCO independently.

Keywords : bromelin enzyme; virgin coconut oil

\section{PENDAHULUAN}

Tanaman kelapa (Cocos nucifera L) merupakan komoditas Indonesia yang memiliki nilai ekonomis tinggi. Virgin Coconut Oil (VCO) merupakan salah satu produk olahan dari buah kelapa yang berpotensial meningkatkan pendapatan masyarakat sehingga memiliki peluang untuk usaha baru yang produktif. VCO merupakan minyak yang didapatkan dari daging buah kelapa tua yang segar yang melalui proses pemerasan dengan atau tanpa penambahan air, dengan pemanasan maksimal $60^{\circ} \mathrm{C}$ atau tanpa pemanasan, dan aman dikonsumsi manusia [1]. $\quad V C O$ banyak memiliki banyak khasiat menurut beberapa penelitian [2]. Peneliti lain menemukan bahwa asam lemak jenuh dan tidak jenuh yang terdapat pada $V C O$ bisa menghambat terjadinya pertumbuhan jamur Candida albicans [3].

Pembuatan VCO dapat dilakukan dengan berbagai variasi metode yakni metode tradisional, metode pemanasan, metode pengasaman, metode sentrifugasi, metode pancingan dan enzimatis. Proses fermentasi yang dilakukan untuk menghasilkan Virgin Coconut Oil (VCO) dengan bantuan enzim. Enzim protease berfungsi berfungsi sebagai pemecah ikatan protein minyak yang terdapat pada emulsi santan. Salah satu enzim yang dapat digunakan untuk memecahkan ikatan lipoprotein dalam emulsi lemak adalah enzim bromelin yang terdapat pada buah nanas (Ananas comosus). Enzim bromelin ini dapat dapat memutuskan ikatan lipoprotein dalam emulsi lemak [4]. Buah nanas adalah buah tropis yang kaya enzim bromelin. Pemanfaatan ezim bromelin ini dapat diaplikasikan pada lingkungan RT 03 RW 03 Kampung Kekupu Kelurahan Rangkapan Jaya, Depok. Pada lingkungan ini banyak buah nenas yang ditanam warga. Biasanya buah nanas hanya dimanfaatkan untuk dibuat sebagai olahan makanan atau minuman, seperti selai buah nenas, es buah.

Mitra ini dipilih karena warga RT 03 RW 03 Kampung Kekupu, Kelurahan Rangkapan Jaya, Depok, Jawa Barat tergolong kedalam keluarga menengah kebawah. Mata pencaharian kepala keluarganya beragam, ada yang pekerjaannya sebagai ojek, jasa service listrik, satpam dan lain-lain. Dan biasanya ibu-ibunya bekerja sebagai asisten rumah tangga. Oleh sebab itu ibu-ibu yang tinggal di lingkungan ini ingin menambah keahlian sehingga dapat meningkatkan penghasilan keluarga. 
Dengan adanya kegiatan pengabdian ini diharapkan terjadi peningkatan wawasan mitra dan masyarakat umum tentang Virgin Coconut Oil (VCO) dan kandungan-kandungan zat dalam Virgin Coconut Oil (VCO) sehingga bermanfaat bagi kesehatan. Kegiatan ini mendorong kreativitas sehingga mitra termotivasi untuk mengaplikasikan praktek pembuatan Virgin Coconut Oil (VCO) dari enzim bromelin yang didapatkan dari buah nanas. Manfaat lainnya yang didapat dari program ini yakni membantu mitra untuk menggali kemampuan dan ketrampilannya agar bisa menyelesaikan masalah (capacity building). Dengan demikian, mitra dapat menambah penghasilan keluarganya.

\section{METODE KEGIATAN}

Pelaksanaan program diawali dengan pendataan, penjaringan subyek (kelompok target), dan sosialisasi program di lokasi mitra. Setelah itu, mitra yang terdiri dari ibu ketua PKK RT 03 RW 03, ibu-ibu rumah tangga, dan tim penggerak PKK, diminta kesediaannya untuk ikut berpartisipasi dan bekerja sama dalam program. Tahapan program kegiatan diawali dengan penyuluhan mengenai Virgin Coconut Oil (VCO), zat-zat kimia yang dalam buah kelapa (Cocos nucifera), buah nenas (Ananas comosus), dan Virgin Coconut Oil (VCO). Selanjutnya dipaparkan kegunaan dan keunggulan Virgin Coconut Oil (VCO) oleh narasumber. Tahap selanjutnya praktek pembuatan Virgin Coconut Oil (VCO) dari buah nanas yang dipandu oleh tim pengabdian. Tahapan berikutnya, narasumber memberikan materi tentang pengemasan yang aman pada penyimpanan minyak ini.

\section{KARYA UTAMA}

Tim pengabdian melakukan pembuatan $V C O$ menggunakan enzim bromelin yang didapatkan dari buah nanas. Pada awalnya dibuat pembuatan krim santan untuk bahan minyak kelapa [4]. Kelapa yang digunakan ialah kelapa yang tua dan segar [1]

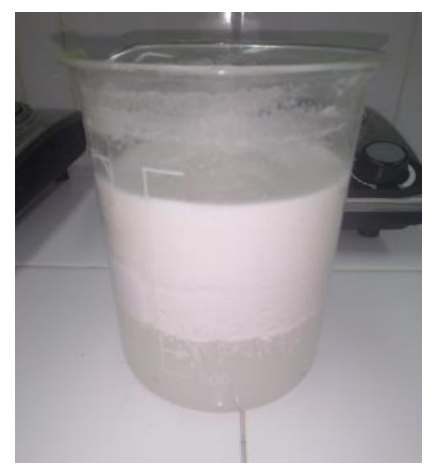

\section{Gambar 1. Krim santan}

Setelah itu dilanjutkan dengan pembuatan enzim bromelin dari buah nanas. Untuk menghasilkan enzim ini maka digunakan kulit, daging dan bonggol buah nanas muda yang dikerjakan secara terpisah [4]. Penggunaan buah nanas muda karena keaktifan bromelin lebih tinggi dibandingkan buah nanas yang tua.

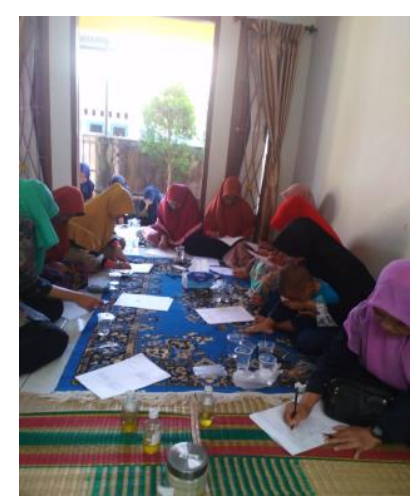

Gambar 2. Pembuatan VCO 


\section{ULASAN KARYA}

Penggunaan buah nanas pada pembuatan VCO ini karena banyak buahan ini yang ditanam oleh penduduk di daerah Kampung Kekupu. Pemilihan menggunakan metode ini karena pengerjaannya mudah dan dapat menggunakan peralatan sederhana. Disamping itu beberapa peneliti telah melakukan penelitian yang menyatakan bahwa enzim bromelin yang terdapat pada kulit, daging dan bonggol buah nanas dapat menghasilkan VCO [8], [9]. Untuk mendapatkan pencampuran yang sempurna antara krim santan dan enzim bromelin diperlukan pengadukan menggunakan alat sentrifugasi. Tetapi karena alat ini tidak ada maka menggunakan sendok sayur.

Ada kendala-kendala yang dihadapi pada pembuatan krim santan yakni pengerjaan yang kurang higienis, botol penyimpanan santan tidak tertutup rapat, pemisahan krim dan skim (air santan) yang kurang baik karena dilakukan menggunakan sendok sayur sehingga pemisahan tidak sempurna. Oleh sebab itu masyarakat Kampung Kekupu ini diinformasikan agar dalam pelaksaaan tahap ini kerja yang higienis agar VCO yang dihasilkan berkualitas baik, botol penyimpanan bertutup rapat sehingga mengurangi terjadinya kontaminasi. Adapun untuk pengambilan ialah dengan cara menyedot lapisan skim dan air menggunakan selang plastik kecil lalu diletakkan dalam suatu wadah [10].

Setelah pencampuran enzim bromelin dan krim santan maka harus disimpan dalam topless tertutup selama waktu tertentu. Kondisi penyimpanan dean wadah penyimpanan merupakan hal yang harus diperhatikan untuk mendapatkan produk $V C O$ yang baik. Setelah itu, terbentuk dua lapisan yakni lapisan minyak, lapisan blondo yang bercampur dengan air. Pada saat pengambilan $V C O$ dari topless menggunakan sendok secara manual. Mitra pengabdian kadang-kadang kurang hati-hati dalam pengambilan $V C O$ ini sehingga lapisan blondo dan air ikut terbawa. Untuk itu diajarkan cara pengambilan $V C O$ yang benar. Tahap selanjutnya diajarkan cara pengemasan dan penyimpanan $V C O$ [1]. Suhu dan cahaya berpengaruh pada umur simpan $V C O$. Adanya hidrolisis trigliserida menjadi gliserol dan asam lemak bebas oleh enzim lipase yang mengakibatkan tengik pada $V C O$. Apabila kemasan yang digunakan tembus cahaya maka mempercepat reaksi kerusakan pada minyak [11].

\section{DAMPAK DAN MANFAAT KEGIATAN}

Pada awal kegiatan pengabdian dilakukan penyebaran angket untuk mendapatkan informasi tentang pengetahuan peserta terhadap VCO, kegunaan dan proses pembuatannya. Berdasarkan hasil angket $74 \%$ peserta belum mengenal tentang $V C O$ baik itu pemanfaatan atau kegunaan maupun cara membuatnya. Sedangkan $26 \%$ telah mengetahui informasi tentang $V C O$ dan kegunaannya, akan tetapi mereka belum mengetahui cara-cara pembuatan $V C O$.

Evaluasi dilakukan setelah tim melakukan pemaparan dan diskusi bersama peserta yaitu dengan menyebarkan kembali angket dan angket 
disi oleh peserta kegiatan. Berdasarkan hasil evaluasi $86,7 \%$ peserta berpendapat bahwa materi yang diberikan pada kegiatan ini mudah dipahami.. Kemudian 93,3 \% peserta merasakan manfaat dari kegiatan ini, dapat membuat VCO dengan bantuan nanas yang cepat, praktis dan dapat dilakukan sendiri sehingga menurut mereka kegiatan ini perlu dilakukan secara rutin dan merekomendasikan ibuibu lainnya untuk mengikuti kegiatan ini.. Keberhasilan dan keberlanjutan pengembangan program secara mandiri oleh mitra juga dapat dilihat dari besarnya motivasi dan kemauan mitra untuk menyebarluaskan pengetahuan tentang kandungan yang terdapat dalam Virgin Coconut Oil (VCO) yang bermanfaat bagi kehidupan pada keluarga atau masyarakat umum, serta keaktifan mitra untuk melakukan pembuatan $V C O$ secara mandiri dengan menggunakan buah nanas sesuai buku panduan yang telah dibagikan oleh tim. Setelah selesai program ini maka pada masyarakat mitra akan terbentuk sistem yang mampu menerapkan hasil dari pengabdian ini.

Evaluasi program juga dapat dilakukan dengan melihat parameter keberhasilan yang meliputi perubahan sikap dan perilaku secara konsisten yang ditunjukkan oleh mitra yaitu antusiame mitra dalam pembuatan $V C O$ secara mandiri karena bermanfaat pada berbagai bidang dan dapat menambah penghasilan keluarga), bertambahnya pemahaman dan pengetahuan mitra tentang $V C O$, mitra memiliki keterampilan untuk melaksanakan pembuatan Virgin Coconut Oil(VCO) dari buah nanas (achievements).

Final outcomes yang diharapkan muncul dari program pengabdian ini ialah dihasilkannya kelompok masyarakat yang memiliki pengetahuan dan pemahaman untuk menghasilkan VCO menggunakan metode enzim enzim bromelin serta memiliki ketrampilan untuk membuat, mengemas $V C O$ secara mandiri.

\section{KESIMPULAN}

Pada kegiatan pengabdian ini 86,7 $\%$ peserta berpendapat bahwa materi pelatihan mudah dipahami. Sebanyak 93,3 $\%$ peserta memperoleh banyak manfaat dari kegiatan ini. Selanjutnya mitra dapat membuat $V C O$ secara mandiri karena bermanfaat pada berbagai bidang dan dapat menambah penghasilan keluarga. Mereka terlihat antusias karena dapat memanfaatkan buah nanas yang tumbuh disekitar rumah untuk menghasilkan VCO yang pada pembuatannya relatif sederhana dan menggunakan alat yang sederhana.

\section{PENGHARGAAN (opsional)}

Ucapan terima kasih disampaikan kepada LPPM Universitas Muhammadiyah Prof DR Hamka yang telah memberikan dana pada kegiatan ini. Ucapan terima kasih juga dihaturkan pada masyarakat RT 03 RW 03 Kampung Kekupu, Depok sebagai mitra kegiatan pengabdian ini.

\section{DAFTAR PUSTAKA}

[1] B. S. Nasional, "Minyak kelapa virgin (VCO)," Indonesia, p. 1-36, 2008.

[2] T. C. Wallace, "Health Effects of Coconut Oil - A Narrative Review of Current Evidence," Journal of the american college of nutrition, vol. 0, no. 0, p. 1-11, 2018.

[3] A. Novilla, "Komposisi asam lemak minyak kelapa murni (Virgin Coconut 
Oil) yang berpotensi sebagai anti kandidiasis," Jurnal kimia dan pendidikan, vol. 2, no. November, p. 161-173, 2017.

[4] T. I. Sari, "Pembuatan VCO dengan metode enzimatis dan konversinya menjadi sabun padat transparan," Jurnal teknik kimia, vol. 17, no. 3, p. 50-58, 2010.

[5] R. Silaban, "Pembuatan Virgin Coconut Oil (VCO) melalui kombinasi teknik fermentasi dan enzimatis menggunakan ekstrak nenas," Jurnal pendidikan kimia, vol. 1, no. 1, p. 9199, 2014.

[6] D. Sagala, "Studi pembuatan minyak kelapa murni secara enzimatis dengan menggunakan berbagai tingkat konsentrasi enzim nanas pada dua jenis kelapa," Jurnal agroqua, vol. 11, no. 1, p. 24-28, 2013.

[7] M. F. FM, "Analisis jenis dan konsentrasi enzim terhadap daya simpan VCO (Virgin Coconut Oil)," Jurnal teknologi Industri pertanian, vol. 6, no. 2, p. 112-117, 2012.

[8] R. P. Hutagaol and N. M. Santi, "Pembuatan minyak kelapa menggunakan kulit nanas," Jurnal sains natural universitas nusa bangsa, vol. 3, no. 2, p. 173-183, 2013. 